\title{
Diagenetic history of the upper Tanglewood Member (upper Ordovician) of the Lexington Limestone, central Kentucky, U.S.A. with special emphasis on petrographic differences between deformed and undeformed beds
}

\author{
*Dibya Raj Koirala and Frank R. Ettensohn \\ University of Kentucky, Lexington, Kentucky, U.S.A. \\ *(Corresponding email: dibya.koirala@uky.edu)
}

\begin{abstract}
Petrographic study was carried out for the upper Tanglewood Member (upper Ordovician) of the Lexington Limestone in order to understand its diagenetic history and predict whether the cementation is pre-deformational or post-deformational by comparing the deformed and undeformed beds of the same horizon. This study shows that the diagenetic processes, which have modified the sequence of the upper Tanglewood Member of the Lexington Limestone, consist of micritization, cementation, compaction, dolomitization and internal filling. Moreover, it indicates that the main episode of cementation took place after the sediment deformation.
\end{abstract}

Keywords: Micritization, dolomitization, upper Ordovician, Lexington Limestone, diagenetic history, soft-sediment deformation

Received: 1 March 2017

Revision accepted: 30 May 2017

\section{INTRODUCTION}

The Ordovician Lexington Limestone (Trenton Limestone in subsurface), initially named by M. J. Campbell in 1898, is an irregular, facies-mosaic-type unit, especially in upper parts of the unit in central Kentucky (Cressman 1973; Ettensohn 1992). Beyond central Kentucky, in the subsurface, the unit is more tabular and uniform in thickness and is called the Trenton Limestone. In central Kentucky, the Lexington Limestone is greater than $100 \mathrm{~m}$ thick and may be as young as early Edenian in age (Cressman 1973; Shaver 1985) (Fig. 1), whereas in surrounding parts of the Lexington Platform, its thickness is $15-60 \mathrm{~m}$ and it is no younger than midChatfieldian in age (Fig. 1). The additional thickness of the Lexington Limestone in central Kentucky comprises a series of shallow-water carbonate shoal complexes, composed of calcarenites and calcirudites that intertongues with mid-ramp, nodular carbonates and shales (Millersburg Member) (Fig. 1). Ettensohn (1991) called this shallow-water carbonate shoal complex the Tanglewood buildup (Fig. 1). This shoal complex has been divided into lower tongue, middle tongue and upper tongue (Figs. 1, 2) (Ettensohn et al. 2002). Beyond central Kentucky, equivalent horizons of the Tanglewood buildup are represented by the deeper water units of Clays Ferry, Kope or Point Pleasant Formations (Fig. 1). Overlying the Lexington/ Trenton Limestone are shaly units that include the Maquoketa, Clays Ferry, Kope and Point Pleasant formations.
As in other parts of the Lexington Limestone, the upper Tanglewood Member also contains numerous deformed horizons which can be traced across long distances (e.g., Koirala et al. 2016). Some of the deformed horizons in lower and middle parts of the Lexington Limestone have been interpreted to represent seismogenic deformation (seismite) by various researchers (e.g., Pope et al. 1997; Rast et al. 1999; Ettensoh et al. 2002; Jewell and Ettensohn 2004). Similarly, McLaughlin and Brett (2004) has given general interpretation of the deformed horizons in the upper Tanglewood and its equivalent horizon as seismite.

Sediment behavior under stress is an important phenomenon that should be tested by comparing the petrophysical properties in undeformed and deformed portions of the same sediment horizon, both in terms of preferred orientation of constituent grains and cementing materials. No such microscopic studies regarding deformed versus undeformed portions of soft-sediment-deformation horizons has currently been performed. In addition to diagenetic history and depositionalenvironment interpretation, this study will try to address some of the petrographic differentiation that occurs during softsediment deformation by analyzing petrographic variation between deformed and undeformed parts of the same horizon. The deformed horizons in the upper Tanglewood Member contains numerous deformational structures, such as balland- pillow structures, diapirs, contorted bedding, folding and homogenized beds. 


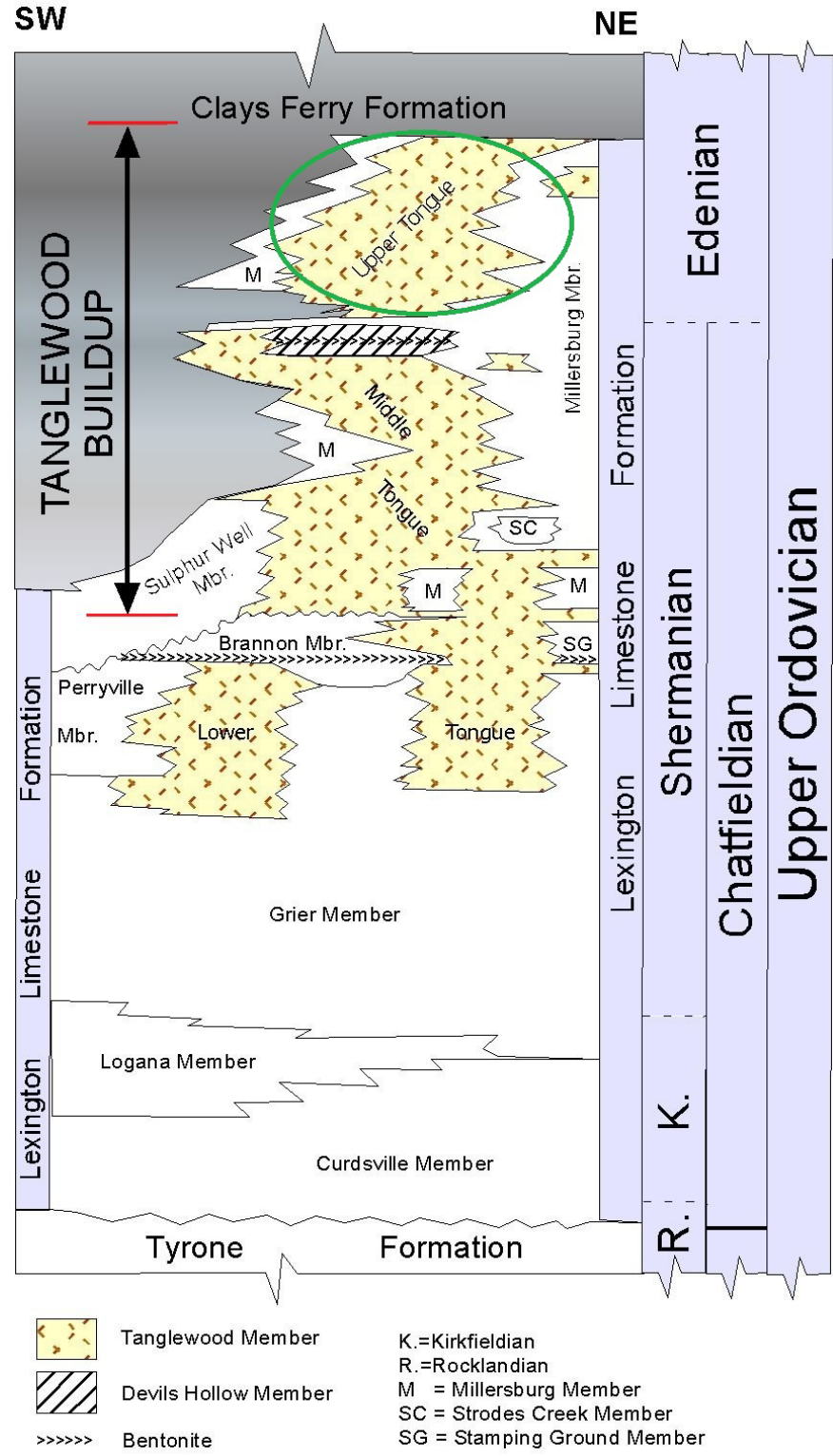

Fig. 1: Interpretive stratigraphic column showing the nature of the Tanglewood buildup and the position of the upper tongue of the Tanglewood Member of the Lexington Limestone in central Kentucky, relative to the position of Millersburg Member or Clays Ferry Formation at the base of the unit . The subtle unconformity at the base of the Lexington Limestone represents the breakup of the Blackriverian carbonate platform and the inception of the Taconic tectophase of the Taconian Orogeny (adapted from Ettensohn et al. 2002).

\section{SAMPLING AND TESTING METHODOLOGY}

During field studies, block samples (minimum $15 \mathrm{~cm} \times 10 \mathrm{~cm} \times 10 \mathrm{~cm}$ ) were collected from deformed and undeformed parts of the same horizon. The samples were carefully selected to avoid any signs of weathering and macroscopic heterogeneity (e.g., veins, fractures, etc.). All of the block samples were collected from fresh profiles. Then thin sections were prepared from these samples. While making thin sections, the slides were labelled to differentiate up and down

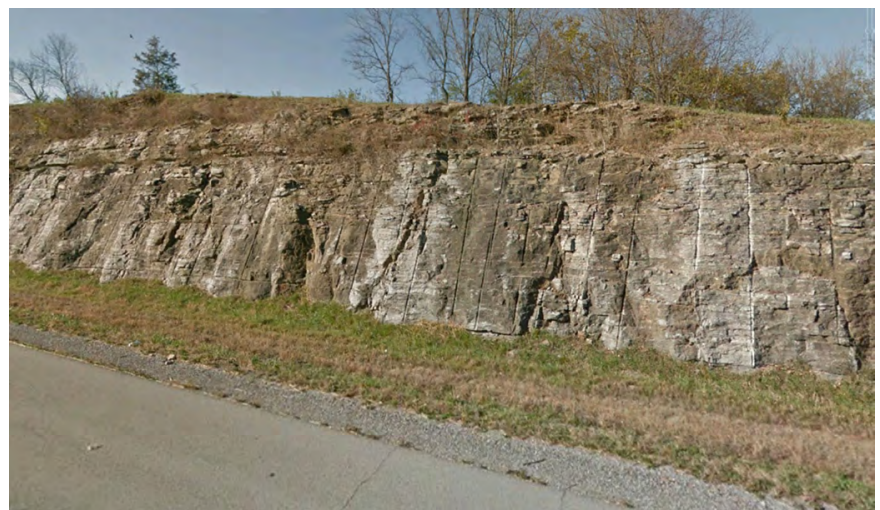

Fig. 2: Exposure of the upper Tanglewood Member of the Lexington Limestone along US highway 127 in Anderson County, KY (38 $\left.{ }^{\circ} 5^{\prime} 45.60^{\prime \prime} N, 8^{\circ} 55^{\prime} 9.90^{\prime \prime} W\right)$.

orientations on the sample. For the purpose of distinguishing between calcite and dolomite, all sections were stained with Alizarin red-S.

\section{PETROGRAPHY}

The upper Tanglewood limestones consists mainly of packstones and grainstones (Fig. 3). The major components are skeletal and non-skeletal grains, abundant sparry-calcite cement, and a few quartz grains. A matrix of micrite is rarely present, but micritization of the grains is abundant. The grain size also ranges from very fine-grained (silt-size) to coarsegrained (rudite-size) depending upon location in the vertical and horizontal profiles. Equivalent horizons in the Clays Ferry Formation are finer-grained than their counterparts in the upper Tanglewood. The results of the microscopic studies are briefly discussed in the following sections.

\section{Characteristic grains (Allochem composition)}

\section{Skeletal grains}

Skeletal grains are mostly sand-size or larger (Fig. 3). Shell shapes are generally well-preserved. Recrystallization of original shell structures to sparry calcite is also quite common. The original microstructure of the grain, in most cases, has been obliterated by diagenesis, but the micritic envelope around the boundary maintains the original shape of the skeletal grain. Syntaxial-rim cements on crinoids are abundant. The thin coatings are composed of dark micrite.

\section{Non-skeletal grains}

Non-skeletal grains are less abundant and mainly consist of peloids and lesser quantities of intraclasts (Figs. 4, 5). Intraclasts are more common in deformed beds. Presence of whole fossils in intraclasts suggests that the winnowed platform-edge zone was very shallow and that the intraclasts were formed by reworking of semi-lithified sediments by moderate currents (Azizi et al. 2014). Peloids are occasional in some samples and are surrounded by sparry calcite cement (Fig. 5). The presence of fecal pellets usually indicates lowenergy, warm seas supersatured with respect to $\mathrm{CaCO}_{3}$ (Scoffin 1987). They may have been derived from deeper portions of the shoal complex. 


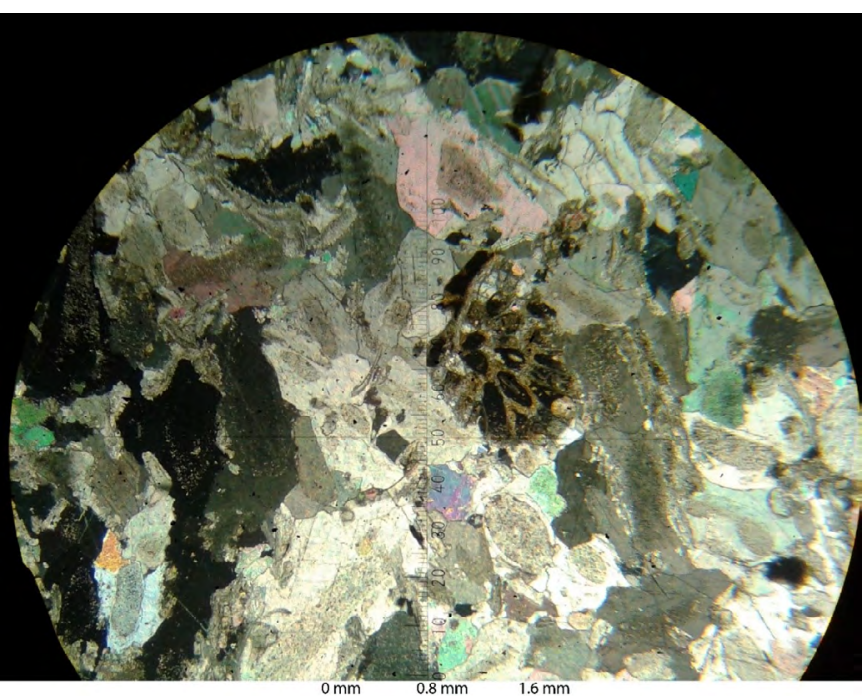

Fig. 3: Photomicrograph of the thin section (25X) under XPL. Photograph showing an upper Tanglewood limestone in thin section $(25 \mathrm{X})$ under XPL. Note the sparry calcite cement between the grains, syntaxial-rim cement around echinoderm grains, and allochems of bryozoan and brachiopod fragments, among others. The bryozoan zooarium in the upper right quadrant is infilled with phosphorite. The sample was taken from an undeformed horizon from Anderson County, KY (38 ${ }^{\circ} 05^{\prime} 45.45^{\prime \prime} \mathrm{N}, 8^{\circ}$ 55'09.66"W).

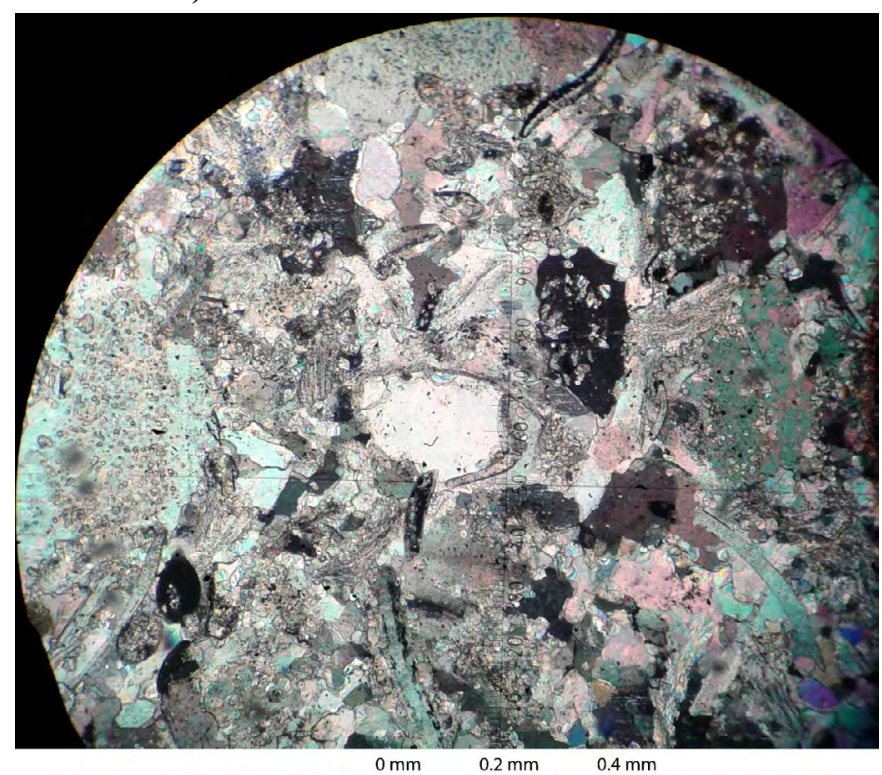

Fig. 4: Photomicrograph of intraclasts in thin section (100X). Photomicograph showing an upper Tanglewood limestone in thin section (100X) under XPL Note the intraclasts on upper right-hand quadrangle. The sample was taken from a deformed portion of the lower deformed horizon from Anderson County, KY $\left(38^{\circ} 3\right.$ ' 30.90" N, 84 ${ }^{\circ} 55^{\prime}$ $15.30 " W)$. Note the lack of well-defined grain orientation.

\section{DIAGENESIS}

After deposition, the largely biochemical sediments get buried under successive layers of younger sediments. The increasing temperatures and pressures encountered during

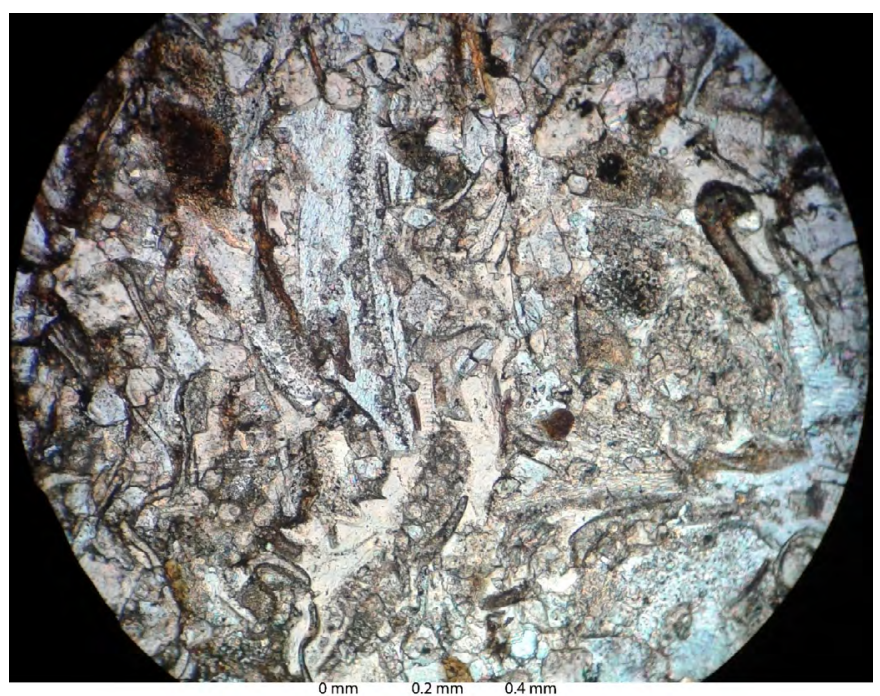

Fig. 5: Peloids and micrite coatings in a thin-section photomicrograph (100X). Photomicrograph showing an upper Tanglewood limestone in thin section (100X) under XPL Note the dark-brown rounded grains (peloids) in the sample. Also, note the micrite coatings on some allochems. The sample was taken from an undeformed portion of deformed horizon from Georgetown, KY $\left(38^{\circ} 16^{\prime} 15.52^{\prime \prime}\right.$ $\left.\mathrm{N}, 8^{\circ} 33^{\prime} 09.03^{\prime \prime} \mathrm{W}\right)$. Note the preferential orientation of elongate grains.

burial bring about diagenesis of the sediments, leading to dissolution and destruction of some constituents, generation of some new minerals in the sediment, and eventually consolidation and lithification of the sediments into sedimentary rock (Boggs 2009). Petrographic investigations on the basis of randomly selected samples indicate that the diagenetic processes, which have modified the sequence of the upper Tanglewood Member of the Lexington Limestone, consist of micritization, cementation, compaction, dolomitization and internal filling.

\section{Micritization}

Micritization is a relatively weak marine diagenetic process which takes place in disturbed or intermittently disturbed shallow-water environments. In this process, carbonate grains are required to remain on the seafloor for a long period of time rather than being quickly buried (Wei 1995; Kabanov 2000). Micritization is the process whereby the margins of carbonate grains are replaced by micrite at or just below the sediment/ water interface. In this process, microbes attack the grains by boring small holes in them, which are later filled with micritic cement (Adams and MacKenzie 1998). Micritization of grains occurs in the active marine phreatic zone (Hartmann and Beaumont 2000). Endolithic algae, fungi, and bacteria play a major role in bioerosion by producing micritic envelopes, occurring within the phreatic zone (Bathurst 1980). Repeated micritization may lead to destruction of the original grain structure. Micritization is obvious with a dark rim around skeletal grains such as brachiopods and bryozoans in the studied limestones (Fig. 5). 


\section{Cementation}

Cementation is the process of precipitation of space-filling crystals between the grains (Adams and MacKenzie 1998). The carbonate cementation process is initiated soon after deposition, during which intergranular pore space is progressively reduced, producing systematic changes in petrophysical properties. The cementation and diagenesis of carbonates can take place in many settings: in the marine environment during the deposition of the sediment, in the surficial vadose environment, and in the freshwater phreatic environment. The marine phreatic environment, in most cases, is where carbonate sediments originate and begin their diagenetic history. The cementation rate is greatest in the active marine-phreatic environment where three conditions occur (Hartmann and Beaumont 2000):

- $\mathrm{pH}$ increases above 9 due to photosynthesis and respiration of a reef biomass

- $\mathrm{CO}_{2}$ degassing

- Waves, tides, or currents force water through pores (works best at shelf margins where buildup is present or along shoreface).

High-magnesium calcite or aragonite are the only cements that precipitate in the active marine phreatic zone. Both are unstable in Mg-deficient water regardless of whether it is marine, brackish, or fresh, and both tend to alter to low-Mg calcite, because most water is magnesium-deficient. Their common form is isopachous coatings on grains. Cementation and dissolution of carbonates initiated in the marine realm continue during contact with fresh water, along with dewatering, grain orientation and grain breakage during earliest burial compaction. Vadose precipitation begins where water in the vadose zone becomes saturated with $\mathrm{CaCO}_{3}$. Cementation is generally minor and reflects pore-water distribution. Meniscus cement precipitates, where water clings between grains in a meniscus form. Pendulous or microstalactitic cement precipitates where water droplets form underneath grains. No vadose cements were observed in the upper tongue of the Tanglewood, meaning that the unit was never exposed in its depositional setting.

The active freshwater phreatic zone is a terrestrial development. Meteoric water that enters the phreatic zone without passing through the vadose zone, is typically undersaturated with respect to $\mathrm{CaCO}_{3}$ but becomes saturated as it dissolves grains. Based on $\mathrm{CaCO}_{3}$ saturation, the active freshwater phreatic zone may be subdivided into undersaturated and saturated zones. In the under-saturated zone, solution occurs, creating moldic or vuggy porosity. In an active, saturated, freshwater phreatic zone, extensive and rapid cementation occurs (Hartmann and Beaumont 2000). The cement is typically an equant calcite spar that coarsens toward pore centers.

The precipitation of cement is evident in the examined carbonate rocks. It is developed within both intergranular and intragranular pores as well as in fractures. Most of the cements in the upper Tanglewood limestones appear to be late diagenetic burial cements. Mainly two generations of sparrycalcite cementation are recognized in the upper Tanglewood limestones: freshwater phreatic cement between the grains and within the grains (intergranular and intrgranular cements), and cementation in fractures.

The earliest generation of cement which is common in the marine environment is fine crystalline-rim cement around allochems (Hartmann and Beaumont 2000). However, such cements are rare in the upper Tanglewood apparently due to later dissolution and reprecipitation in the phreatic environment. The second generation of cement is relatively large in size and fills the spaces between and within allochems and was largely produced by the dissolution of early aragonite cements (Fig. 6). It is characterized by equant, sparry calcite. Drusy calcite spar is also a characteristic pore-filling cement with an increasing crystal size toward the center of most pores. Syntaxial-rim cement is obviously seen on crinoids (Fig. 3), and this generation of cement is characteristic of the freshwater-phreatic environment as indicated by its geometry. A third generation of cement occupies fractures (Fig. 7). Therefore, cementation in these rocks primarily reflects latestage diagenesis after burial in the freshwater phreatic zone.

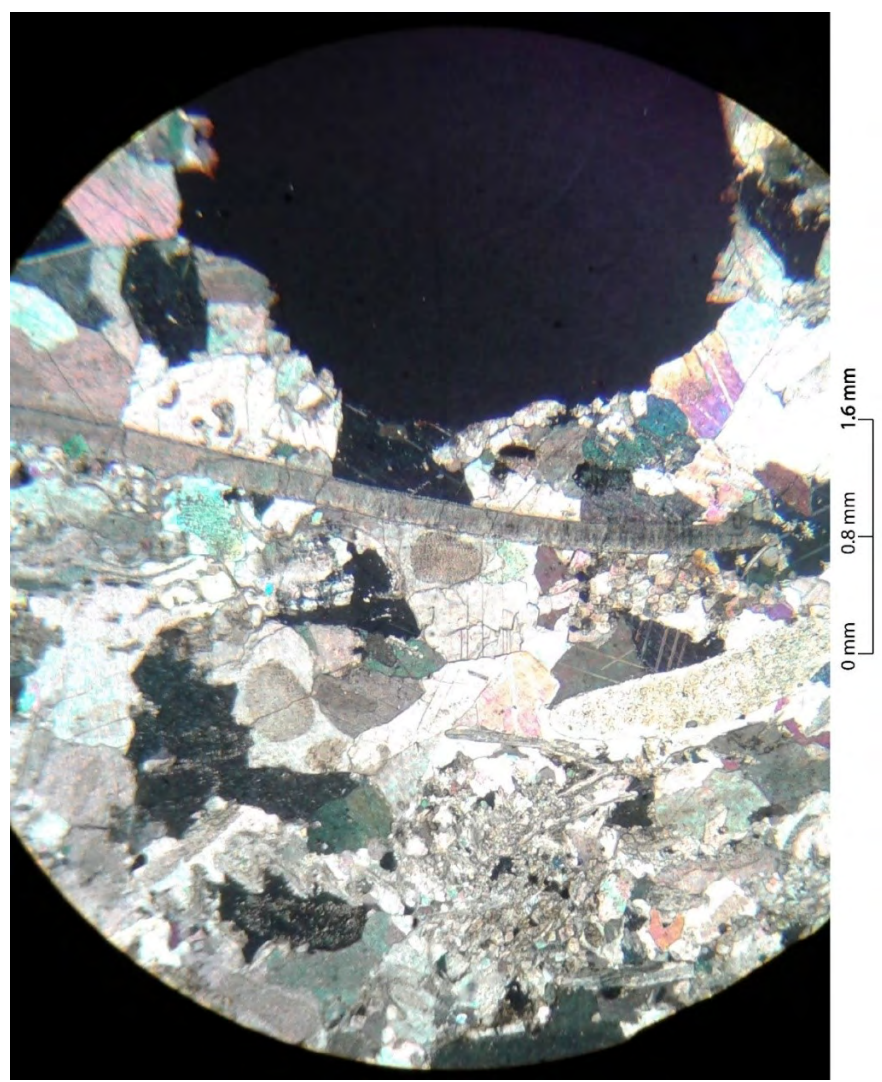

Fig. 6: Sparry calcite cement in a thin-section photomicrograph (100X). Photomicograph showing an upper Tanglewood limestone in thin section (25X) under XPL. Note the abundant sparry-calcite cement. The sample was taken from an undeformed horizon from Anderson County, KY (38 $\left.{ }^{\circ} 05^{\prime} 45.45^{\prime \prime} \mathrm{N}, 84^{\circ} 55^{\prime} 09.66^{\prime \prime} \mathrm{W}\right)$. The dark hole on the upward side of the slide is a cut in the thin-section chip to represent the up direction. 


\section{Compaction}

Compaction processes have been observed in the studied limestones. Before cementation, compaction takes place dominantly by mechanical processes. With increase in overburden pressure, more stress is placed on the grain-tograin contacts, and compaction starts to proceed by chemical dissolution at grain boundaries. Both mechanical and chemical compaction processes start under an overburden of tens to a few hundred meters. Meyers (1980) stated that most nonstylolitic compaction is completed before burial by about $1980 \mathrm{~m}$ of overburden. Under a thicker overburden, a welldeveloped, thorough-going stylolitic compression takes place. Both types of compaction are observed in the studied samples.

\section{Mechanical compaction}

Mechanical compaction is associated with dehydration, porosity reduction, and significant decrease of up to one quarter of the original thickness of sediments (Flügel 2004). This process includes the repacking of allochemical components in carbonates. The parallelism of bryozoans can even be visible in hand specimens. The types of grain contacts produced by mechanical compaction in the studied limestones reflect point and tangential contacts.

\section{Chemical compaction or pressure dissolution}

Chemical compaction is a potentially important cause of the dissolution of calcium carbonates and the formation of stylolites, which penetrate all the studied rocks, apart from the allochems. Later, the dissolved calcium carbonate may be precipitated in suitable openings or fissures, forming calcite veinlets (Wanless 1979). Progressive solution leads to alteration of the grain-tograin contacts from the original point contacts, through planar (or tangential) contacts to interpenetration (concavo-convex), and sutural grain-to-grain contacts. Chemical compaction is a very important diagenetic process in a burial environment. In addition, producing a pressure-dissolution fabric, such as stylolites, leads to the dissolution of grains and matrix, which is an important source of burial-calcite cement (Zhang et al. 2006). Chemical compaction processes within the upper Tanglewood limestone resulting in pressure solution are not obvious in thin section; only interpenetrating grains are obvious (Fig. 8).

\section{Internal filling}

Internal filling (or fracture and cavity filling) is common in the studied rocks (Fig. 7). Fractures are predominantly filled with drusy and granular, mosaic, calcite cement, which indicates a meteoric phreatic environment at the mesogenesis stage. The later diagenetic stage, or mesogenesis, involving increased burial and compaction, leads to grain reorientation, breakage and deformation of bioclasts, development of pressure-solution seams, micro-stylolites and stylolites. Formation of coarse sparry calcite cement (Figs. 3,8 ) probably developed as a result of re-precipitation following pressure dissolution.

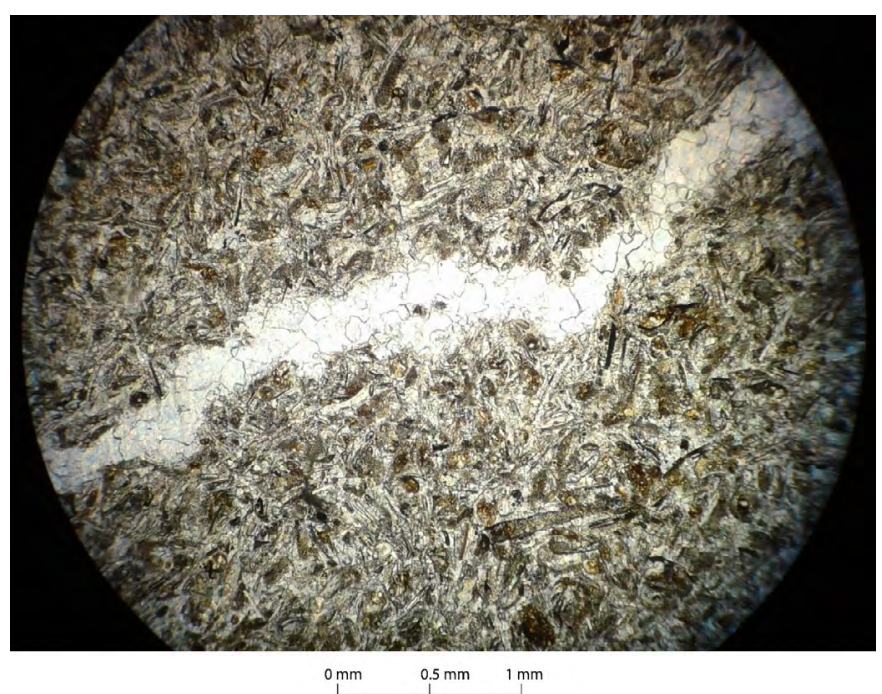

Fig. 7: Internal fracture filling in a thin-section photomicrograph (100X). Photomicrograph showing an internal fracture filling by sparry calcite in an upper Tanglewood limestone in thin section under XPL (40X). The sample was taken from a ball-and-pillow structure in the deformed horizon from Georgetown, $\mathrm{KY}\left(3^{\circ}{ }^{\circ} 16^{\prime}\right.$ $\left.15.52^{\prime \prime} \mathrm{N}, 8^{\circ}{ }^{\circ} 33^{\prime} 09.03^{\prime \prime} \mathrm{W}\right)$. Note the random orientation of grains.

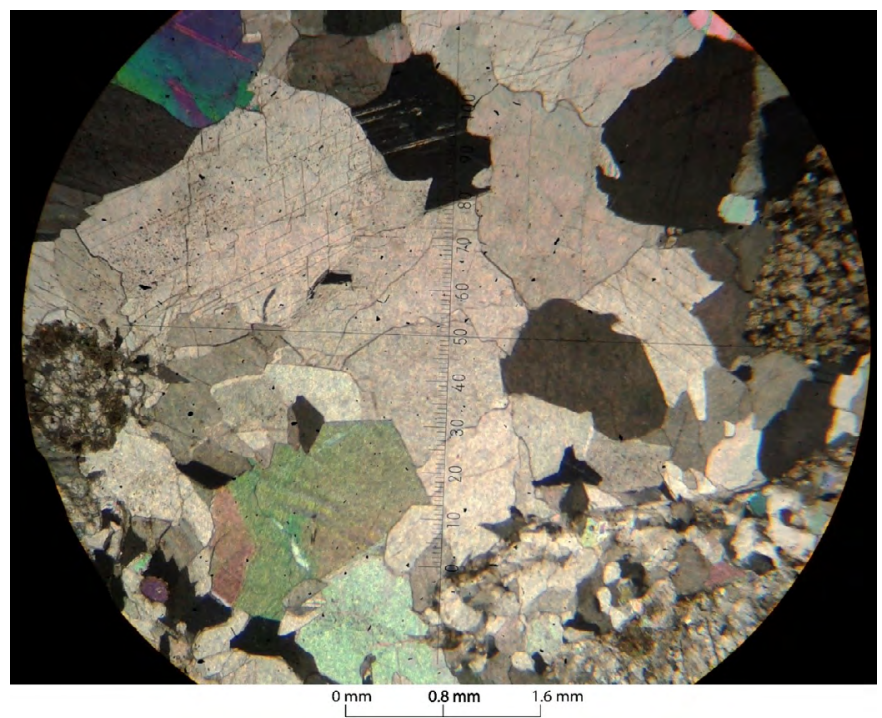

Fig. 8: Interpenetrating grains in a thin-section photomicrograph (100X). Photomicrograph showing interpenetrating grains in an upper Tanglewood limestone in thin section under XPL (25X). Note the grain contacts. The sample was taken from an undeformed horizon from Anderson County, KY (38 $05^{\prime} 45.45^{\prime \prime}$ N, 84 ${ }^{\circ} 55^{\prime} 09.66 "$ W).

\section{Dolomitization}

Dolomitization is a diagenetic process that converts limestones to dolostones through a microchemical process of calcium carbonate dissolution and dolomite precipitation. Dolomitization can change the rock fabric and the petrophysical properties significantly because the dolomite crystals are commonly larger than the replaced limestone grains. Dolomite cement systematically grows on dolomite 
crystal faces, reducing porosity. Dolomitization requires the addition of large quantities of magnesium through fluid flow. Dolomitization is quite obvious in most upper Tanglewood samples. Mainly euhedral crystals are present (Fig. 9). The source of extra magnesium probably came from the dissolution of high-magnesium cement, echinoderm grains, or from clays.

\section{PETROGRAPHIC DIFFERENCE BETWEEN DEFORMED AND UNDEFORMED PORTIONS OF A DEFORMED HORIZON}

In comparing the deformed and undeformed portions of the same horizon, it appears that the main difference lies in the preferred orientation of elongate grains. In undeformed portions of the horizon, the elongate grains appear to be preferentially oriented; the grains are aligned parallel to the original depositional plane (Fig. 10).

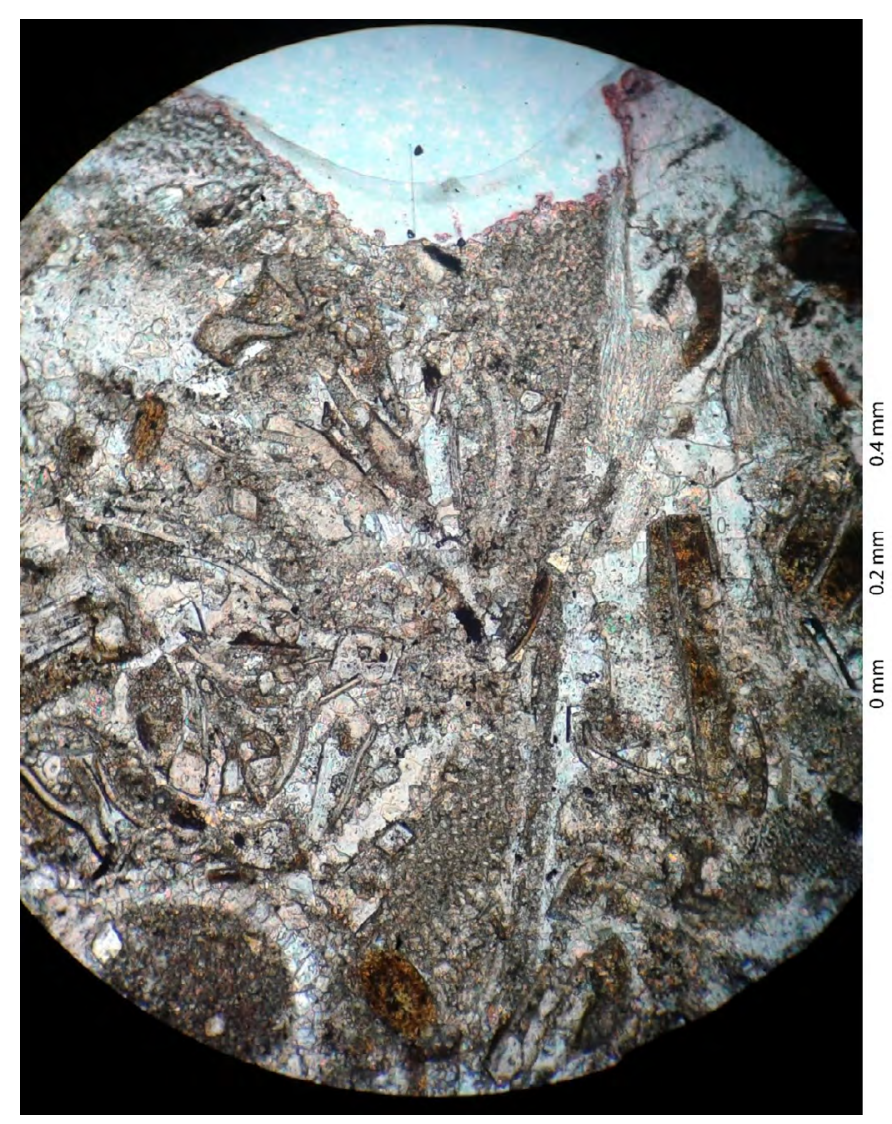

Fig. 9: Dolomitization in a thin section photomicrograph. Photomicrograph showing dolomitization in an upper Tanglewood limestone in thin section under XPL (100X). Also, note the haphazard orientation of elongated grains (almost vertical to depositional plane or at least at significantly inclined angles to the depositional plane) $(100 X)$ relative to the depositional plane. The sample was taken from the deformed horizon from Georgetown, KY $\left(38^{\circ} 16^{\prime} 15.52^{\prime \prime} \mathrm{N}, 8^{\circ} 33^{\prime} 09.03^{\prime \prime} \mathrm{W}\right)$. The indentation at the top side of the thin section is a cut in the thin-section chip to show the up direction. The dark-brown grains are phosphatized peloids and fossil fragments.

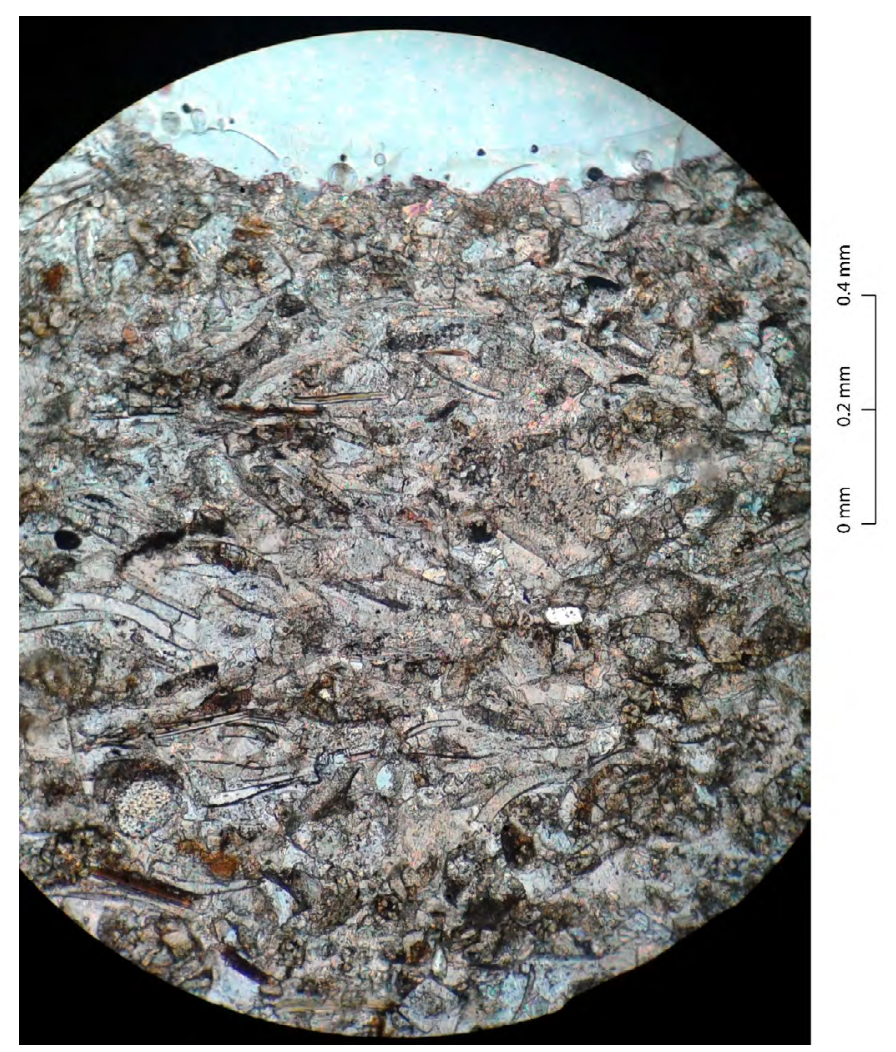

Fig. 10 Preferential orientation of elongated allochems in a thin-section photomicrograph. Photomicrograph showing the preferential orientation of elongated allochems parallel to the former depositional plane under XPL (100X). The sample is taken from an undeformed portion of the deformed horizon from Georgetown, KY $\left(3^{\circ} 1^{\prime} 15.52^{\prime \prime}\right.$ $\left.\mathrm{N}, 84^{\circ} 33^{\prime} 09.03^{\prime \prime} \mathrm{W}\right)$. The indentation on the top side of the photograph is a cut in the thin-section chip to show the up direction. The dark-brown grains are phosphatized peloids and fossil fragments.

Waves and storms typically transport sediment to a particular location and deposit it such that the elongate grains are preferentially oriented; compaction will further enhance this orientation (Fig. 10). In deformed beds, however, the grains are aligned haphazardly or randomly. This is due to the fact that during deformation the original grain alignments get obliterated due to water escaping randomly through the sediment. More precisely, in some cases, the elongate grains appear to be aligned vertically to the depositional plane (Fig. 9). Such orientation can be attributed to the fact that during deformation, the water in this area was escaping vertically. If the water escapes in another direction, the grains will be aligned accordingly.

Another difference between deformed and undeformed sediments comes from the fact that intraclasts are more common in the deformed beds (Fig. 4). This is due to the fact that weakly cemented rock fragments got detached from the host rocks during deformation and were re-cemented during later stages of diagenesis. Dolomitization is common in deformed beds as well as in undeformed beds (Fig. 9). The nature of cement did not show any differences between deformed and undeformed 
beds. It appears that the cementation primarily took place after sediment deformation. Because most of the intact framework of the sediments appears to be preserved, it may be possible that the sediments underwent weak marine cementation before deformation during early diagenesis. This possibility is bolstered by the fact that the rock contains many fragmented intraclasts. Therefore, it may be more realistic to assume that the initial marine cements might have been obliterated during deformation and later stages of diagenesis. The main episode of cementation probably took place after sediment deformation when the sediment came into contact with the ground water during later uplift.

\section{CONCLUSIONS}

The petrographic study of these limestones has concluded that diagenetic modification of the upper Tanglewood limestones commenced with grain micritization. Micritizatiomn was accompanied by equant isopachous-calcite cementation at the eogenesis stage. Then, this equant isopachous (rim) cement was largely removed by dissolution. As the burial depth increased, precipitation of equant sparry-calcite cements was followed by recrystallization of micrite into microsparite. At the mesogenesis stage with increasing burial and compaction, grain orientation and fitted-fabric texture developed, and this in turn led to the development of fractures. Fracture development was followed by precipitation of drusy calcite cement. The final stage of cementation occurred during uplift and deep burial when equant sparry-calcite and syntaxial-rim cements were deposited. Most of this cementation occurred after deformation. Although deformation may have destroyed some of the very early isopachous cements, its main effect was to randomize sediment distribution and generate more fractured intraclasts. Abundant micritization of the skeletal grain indicates that the upper Tanglewood was deposited in disturbed or intermittently disturbed shallow-water environments. Moreover, it indicates that the carbonate grains remained on the sea floor for a long period of time rather than being quickly buried.

\section{ACKNOWLEDGEMENTS}

This study was supported by grants from the Geological Society of America-based upon work supported by the National Science Foundation under Grant No. 1354519 and the Department of Earth and Environmental Sciences, University of Kentucky-Student research support. We are also grateful to Dr. Khum Narayan Paudayal and two anonymous reviewers for their careful and constructive reviews of this paper.

\section{REFERENCES}

Adams, A. E., and MacKenzie, W. S., 1998, A Colour Atlas of Carbonate Sediments and Rocks under the Microscope. Manson, London, $180 \mathrm{p}$.

Azizi, S. H. H., Shabestari, and G. M., Khazaei, A., 2014, Petrography and geochemistry of Paleocene-Eocene limestones in the Ching-dar syncline, eastern Iran. Geoscience Frontiers, v. 5(3), pp. 429-438.

Bathurst, R. G. C., 1980, Stromatactis origin related to sub-marinecemented crust in Paleozoic mudmounds. Geology, v. 8, pp. 131-134.
Boggs, S. Jr., 2009, Petrology of Sedimentary Rocks (2nd ed.). Cambridge University Press, Cambridge, England. 600 p.

Campbell, M. R., 1898. Description of the Richmond quadrangle, Kentucky. U. S. Geological Survey Geologic Atlas, 46 p.

Cressman, E. R., 1973, Lithostratigraphy and depositional environments of the Lexington Limestone (Ordovician) of central Kentucky. U. S. Geological Survey Professional Paper, v. 768, pp. 1-61.

Ettensohn, F. R., 1991, Flexural interpretation of relationships between Ordovician tectonism and stratigraphic sequences, central and southern Appalachians, U.S.A., In: Barnes, C. R., Williams, S. H. (Eds.), Advances in Ordovician Geology. Geological Survey of Canada, Paper, v. 90(9), pp. 213-224.

Ettensohn, F. R., 1992, Regressive facies in the upper Lexington Limestone: Tanglewood-Millersburg relationships. In: Ettensohn, F. R. (Ed.), Changing interpretations of Kentucky geology-layer-cake, facies, Flexure, and Eustacy. Ohio Division of Geological Survey Miscellaneous Report, v. 5, pp. 62-66.

Ettensohn, F. R., Kulp, M. A., and Rast, N., 2002, Interpreting ancient marine seismites and apparent epicentral areas for paleoearthquakes, Middle Ordovician Lexington Limestone, central Kentucky. In: Ettensohn, F. R., Rast, N., Brett, C. E. (Eds.), Ancient Sesmites. Geol. Soc. America, Sp. Paper, v. 359, pp. 177-190.

Flügel, E., 2004, Microfacies of Carbonate Rocks. Springer, Berlin, $976 \mathrm{p}$.

Hartmann, D. J., and Beaumont, E. A., 2000, Predicting Reservoir System Quality and Performance. In: Beaumont, E. A., Hoster, N. H. (Eds.), Treatise of Petroleum Geology/Handbook of Petroleum Geology: Exploring for Oil and Gas Traps. Tulsa, OK: AAPG Publishing, v. 9, pp. 1-154.

Jewell, H. K., and Ettensohn, F. R., 2004, An ancient seismite response to Taconian far- field forces: The Cane Run Bed, Upper Ordovician (Trenton) Lexington Limestone, central Kentucky (USA), Jour. Geody., v. 37, pp. 487-511.

Kabanov, P. B., 2000, Grain micritization as facial indicator in shallow water marine carbonate rocks. Byulletin' Moskovskogo Obshchestva Ispytateley Prirody. Otdel Geologicheskiy, v. 75(4), pp. 39-48 (in Russian with English abstract).

Koirala, D. R., Ettensohn, F. R., and Clepper, M. L., 2016, Eustatic and far-field tectonic control on the development of an intraplatform carbonate-shoal complex: upper tongue of the Tanglewood Member, Upper Ordovician Lexington Limestone, central Kentucky, U. S. A. Sed. Geol., v . 345, pp. 1-18.

McLaughlin, P. I., and Brett, C. E., 2004, Eustatic and tectonic control on the distribution of marine seismites: examples from the Upper Ordovician of Kentucky, U. S. A., Sed. Geol., v. 168, pp. 165-192.

Meyers, J. W., 1980, Compaction in Mississippian skeletal limestones, southwestern New Mexico. Jour. Sed. Petrol., v. 50, pp. 457474.

Pope, M. C., Read, J. F., Bambach, R., and Hofmann, H. J., 1997, Late Middle to Late Ordovician seismites of Kentucky, southwest Ohio and Virginia: sedimentary recorders of earthquakes in the Appalachian basin. Geol. Soc. America Bull., v. 109(4), pp. 489-503.

Rast, N., Ettensohn, F. R., and Rast, D. E., 1999, Taconian seismogenic deformation in the Appalachian orogen and the North American craton. In: Mac Niocaill, C., Ryan, P. D. (Eds.), Continental Tectonics. Geol. Soc. London (Sp. Pub.), v. 164, pp. 127-137.

Scoffin, T. P., 1987, An Introduction to Carbonate Sediments and Rocks. Chapman \& Hall, New York, 274 p.

Shaver, R. H., 1985, Midwestern basin and arches region. American Association of Petroleum Geologist. COSUNA Chart MBA. The AAPG Bookstore, Tulsa. 
Wanless, H. R., 1979, Limestone response to stress: pressure solution and dolomitization. Jour. Sed. Petrol., v. 49, pp. 776-780.

Wei, L. M., 1995, Study on the micritization of carbonate grains by bacteria and algae. Acta Sedimentologica Sinica, v. 13(3), pp. 89-97 (in Chinese with English Abstract).
Zhang, H., Ding, L., Wang, X., Wang, L., Wang, Q., and Xia, G., 2006, Carbonate diagenesis controlled by glacioeustatic sealevel changes: a case study from the Carboniferous-Permian boundary section at Xikou, China. Jour. China Univ. Geosci., v. 17(2), pp. 103-114. 